\title{
ARTIKEL
}

\section{Sanctionering van verkeersongevallen}

\author{
Op het kruispunt van taakstraffen, verkeersdelicten \\ en herstelrecht
}

Jacques Claessen

\section{Inleiding}

Verkeersdelicten zijn er in vele soorten en maten, men leze de Nederlandse Wegenverkeerswet (hierna: WVW) en de jurisprudentie er maar op na. In deze bijdrage ligt de focus hoofdzakelijk op die verkeersdelicten waarbij sprake is van een verkeersongeval met (zwaar) lichamelijk letsel of de dood tot gevolg. Ook die verkeersdelicten zijn er in vele verschijningsvormen. Niettemin leiden zij vrijwel steevast tot beroering - niet alleen bij de direct betrokkenen, maar ook in de samenleving, de media en de politiek.

Zo kan ik me nog goed de Meijelse strafzaak herinneren, waarin een Poolse automobilist terechtstond, omdat hij een tweejarig meisje en haar grootouders had doodgereden. Toen de rechter in eerste aanleg een taakstraf van 120 uur en een voorwaardelijke rijontzegging van één jaar oplegde ( $\mathrm{Rb}$. Limburg 21 november 2014, ECLI:NL:RBLIM:2014:10041), gooide de vader van het meisje uit pure woede en frustratie een stoel naar de rechter - iets wat iedereen op tv kon zien. www.geenstijl.nl kopte: '120 uur fopstraf in Meijelse strafzaak', met daarbij de volgende toelichting: 'De kogel is door de kerk. De Poolse kamikazepiloot die drie fietsers heeft doodgereden in Meijel (Limburg) moet 120 uur schoffelen. WTF?! 120 uur plantsoenendienst voor het doodrijden van een 2-jarig meisje en haar grootouders (67 en 64). Dat kan alleen in Nederland.' De rechtbank kwam niet tot een bewezenverklaring van schuld in de zin van verwijtbare grove onvoorzichtigheid (culpa), omdat voor haar onvoldoende zeker was dat de verdachte harder had gereden dan de toegestane maximumsnelheid. Om die reden kon de rechtbank de verdachte niet veroordelen voor dood door schuld in het verkeer ex artikel 6 WVW (culpoos misdrijf), maar enkel voor het verwijtbaar veroorzaken van hinderlijk gedrag in het verkeer ex artikel 5 WVW (overtreding), ${ }^{1}$ ook al waren er drie doden gevallen.

In hoger beroep werd de verdachte alsnog veroordeeld tot de door het Openbaar Ministerie geëiste celstraf van vijftien maanden en een onvoorwaardelijke rijontzegging van vier jaar (Hof Den Bosch 23 september 2015 ECLI:NL:GHSHE: 2015:3709), omdat het gerechtshof schuld in de betekenis van verwijtbare grove 
onvoorzichtigheid wél bewezen achtte na aanvullend forensisch onderzoek naar de snelheid waarmee de verdachte gereden had. Voor het gerechtshof stond wél met voldoende zekerheid vast dat de verdachte te hard had gereden en dus was er wél sprake van culpa. Kortom: het was de zwaardere kwalificatie (art. 6 WVW in plaats van art. 5 WVW) die tot een zwaardere straf leidde. De vraag is of deze hogere straf ook de genoegdoening heeft gebracht die de nabestaanden wensten.

Belangrijk in dit verband is de uitspraak die de moeder van het meisje in de media deed: 'Hij heeft nooit zijn excuses aangeboden, nooit de moeite genomen om ons te benaderen, nooit berouw getoond en nooit de waarheid gesproken.' In zaken waarin dat wel gebeurt, zie ik als rechter-plaatsvervanger vaak een geheel andere 'dynamiek', hoe vreselijk de gebeurtenissen ook zijn. Dat gebeurde bijvoorbeeld in de strafzaak tegen de 22-jarige automobilist die door met een te hoge snelheid te rijden een 14-jarige fietser aanreed, waaraan laatstgenoemde een blijvend verlamde linkerarm overhield. In het vonnis staat te lezen dat de verdachte 'de ernst van zijn verkeersgedrag en de gevolgen daarvan terdege beseft, dat hij in ernstige mate betreurt dat het verkeersongeval heeft plaatsgevonden, dat hij voor het ongeval verantwoordelijkheid neemt en berouw heeft over zijn schuld' (Rb. Limburg 17 augustus 2015, ECLI:NL:RBLIM:2015:7640). Dit bleek onder meer uit het gegeven dat de verdachte na het ongeval meermalen contact met het slachtoffer had proberen op te nemen en uit zijn als oprecht ervaren spijtbetuiging tijdens de zitting.

In deze strafzaak maakte de vader van de 14 -jarige jongen gebruik van het spreekrecht en hoewel hij vertelde dat het ongeval grote impact had gehad en nog steeds had op zijn zoon en het hele gezin en dat hij de hele gang van zaken ten diepste betreurde, vertelde hij tevens dat hij de berouwvolle en coöperatieve houding van de verdachte op prijs stelde en dat hij, als het aan hem lag, niet naar de gevangenis hoefde. Hij voegde hieraan toe, dat - als hij eerlijk was - ook hijzelf weleens te hard reed en dat hij tot dan toe godzijdank altijd geluk had gehad. Wat een zelfinzicht! Deze verklaring ontroerde de verdachte zo dat deze zich naar de vader omdraaide, waarop een dialoog tussen beiden ontstond. Als rechters ervoeren we de helende werking hiervan en we hebben dan ook ruimte geboden voor deze spontane 'mediation' op zitting. De rechtbank achtte overtreding van artikel 6 WVW bewezen en legde - in afwijking van de door de officier van justitie geëiste onvoorwaardelijke gevangenisstraf van één maand - een taakstraf van 160 uur op en een rijontzegging van één jaar.

Deze twee voorbeelden laten zien dat in het geval van verkeersdelicten waarbij sprake is van een verkeersongeval met (zwaar) lichamelijk letsel of de dood tot gevolg, grote verschillen kunnen bestaan, niet alleen wat betreft de 'feiten' (het verkeersgedrag en de gevolgen daarvan), maar ook wat betreft de wijze waarop verdachten reageren en in het verlengde daarvan de wijze waarop slachtoffers of nabestaanden reageren. Omdat bij de sanctionering niet alleen wordt gekeken naar de ernst van het feit, maar ook naar de persoon van de verdachte en de omstandigheden van het geval (waarbij ook het slachtoffer een rol kan spelen), ligt het voor de hand dat de officier van justitie en de rechter de beschikking heb- 
ben over een groot sanctiearsenaal, zodat recht kan worden gedaan aan en in het concrete geval. Maatwerk bij dit soort verkeersdelicten eist een sanctiepalet waarvan onder meer (herstelgerichte ${ }^{2}$ ) taakstraffen en onvoorwaardelijke gevangenisstraffen deel uitmaken alsook herstelrechtvoorzieningen, waaronder bemiddeling en mediation. ${ }^{3}$

Toch heeft minister Dekker van Rechtsbescherming inmiddels een wetsvoorstel ingediend, waarin hij eenzijdig kiest voor een strengere aanpak van verkeersdelicten. $^{4}$ Deze punitieve aanpak lijkt evenwel tekort te schieten. Immers, zoals bovenstaande voorbeelden laten zien, hebben slachtoffers in het geval van verkeersongevallen in ieder geval óók (en misschien wel meer) behoefte aan een verdachte die berouw toont en excuses maakt, die openheid van zaken biedt en die verantwoordelijkheid wil nemen voor zijn gedrag. In die zaken waarin een en ander om wat voor reden dan ook niet plaatsvindt, lijkt dat inderdaad al snel te leiden tot een roep om zwaardere straffen, zowel bij de slachtoffers of nabestaanden als in de samenleving, de media en de politiek. Echter, aangezien verkeersongevallen vrijwel nooit opzetdelicten (denk aan doodslag ex art. $287 \mathrm{Sr}$ ) zijn, zullen de straffen waarschijnlijk nooit hoog genoeg zijn voor die slachtoffers of nabestaanden die stellen dat zijzelf levenslang hebben. Echt hoge straffen (lees: langdurige onvoorwaardelijke gevangenisstraffen) zijn in het strafrecht terecht gereserveerd voor ernstige opzetdelicten.

Deze bijdrage tracht op een beschrijvende en verkennende wijze drie thema's bij elkaar te brengen: taakstraffen, verkeersdelicten ${ }^{5}$ en herstelrecht; de Nederlandse situatie staat centraal. Daartoe wordt eerst de wettelijke regeling omtrent de taakstraf uiteengezet. Tevens wordt aandacht besteed aan bestaand empirisch onderzoek naar de effectiviteit van de taakstraf in termen van recidivereductie (par. 2). Voorts wordt de bestraffing van verkeersdelicten besproken alsook de consequenties voor de bestraffing van het momenteel aanhangige wetsvoorstel dat strekt tot aanscherping van de strafrechtelijke aansprakelijkheid bij ernstige verkeersdelicten (par. 3). Daarna wordt bezien welke herstelrechtvoorzieningen oftewel -modaliteiten er zijn en hoe herstelgericht taakstraffen zijn en kunnen worden vormgegeven (par. 4). Tot slot beschrijf ik mijn ideaalbeeld als het gaat om de sanctionering van verkeersdelicten in de vorm van een continuüm (par. 5). De bijdrage wordt afgesloten met een uitleiding (par. 6).

2 Zie par. 4.

3 In Nederland wordt onderscheid gemaakt tussen bemiddeling en mediation. Simpel gezegd houdt bemiddeling een proces/gesprek tussen slachtoffer en dader in voor, naast of na het strafproces; dit proces heeft in principe geen invloed op het strafproces en richt zich primair op emotioneel en relationeel herstel. Mediation is een proces/gesprek tussen slachtoffer en dader in het strafproces (de term is 'mediation in strafzaken'), waarbij ook afspraken kunnen worden gemaakt over herstel van schade (wedergoedmaking); met eventueel gemaakte afspraken dienen de officier van justitie en de rechter rekening te houden bij de afdoening/sanctionering (art. 51h lid 2 Sv). Zie voor een nadere toelichting wat betreft deze terminologie: Claessen e.a., 2018.

4 Zie par. 3.

5 In deze bijdrage wordt gefocust op de verkeersdelicten ex art. 5, 5a (voorgesteld) en 6 WVW (zie de kaders). 


\section{Taakstraffen}

Wanneer een delict is gepleegd, kan het Openbaar Ministerie ter zake van strafbare feiten waarop ingevolge de strafwet een maximale gevangenisstraf van zes jaar is gesteld, besluiten de zaak zelf af te doen door middel van het uitvaardigen van een strafbeschikking. Het Openbaar Ministerie legt dan zelf een sanctie op aan de dader (art. 257a Sv e.v.). Het kan daarbij onder meer kiezen voor een geldboete en/of een taakstraf, bij verkeersdelicten te combineren met een rijontzegging van maximaal zes maanden. De oplegging van vrijheidsbenemende sancties is voorbehouden aan de rechter. Kan of wil het Openbaar Ministerie de zaak niet zelf afdoen, dan zal het deze door middel van een dagvaarding voor de rechter brengen. Komt deze tot een bewezenverklaring en acht hij geen strafuitsluitingsgronden aannemelijk, dan dient de rechter te onderzoeken of hij een sanctie gepast acht en, zo ja, welke? ${ }^{6}$ De rechter kan kiezen uit de volgende hoofdstraffen: gevangenisstraf, hechtenis, ${ }^{7}$ taakstraf ${ }^{8}$ en geldboete (art. 9 lid 1 Sr). Ook heeft hij de mogelijkheid om deze straffen te combineren (art. 9 lid $3 \mathrm{Sr}$ ). Zo kan hij een gevangenisstraf (waarvan het onvoorwaardelijke deel maximaal zes maanden bedraagt; art. 9 lid $4 \mathrm{Sr}$ ) combineren met een taakstraf, een gevangenisstraf met een geldboete en een taakstraf met een geldboete. Alle hoofdstraffen kunnen bovendien geheel of gedeeltelijk voorwaardelijk worden opgelegd (art. 14a Sr). ${ }^{9}$

Bij ernstige delicten (wanneer het misdrijven betreft waarop naar de wettelijke omschrijving een gevangenisstraf van zes jaar of meer is gesteld en die een ernstige inbreuk op de lichamelijke integriteit van het slachtoffer tot gevolg hebben) en bij recidive (wanneer voor een soortgelijk delict reeds eerder aan de verdachte een taakstraf is opgelegd en deze is uitgevoerd) is het de rechter inmiddels verboden om te volstaan met de oplegging van een taakstraf; hij is dan verplicht tot oplegging van een onvoorwaardelijke gevangenisstraf, eventueel gecombineerd met een taakstraf of geldboete (art. 22b Sr). Duidelijk is dat de rechter niet gelukkig is met dit in 2012 ingevoerde taakstrafverbod (Bakker, 2016): in bepaalde gevallen waarin dit volgens de strafwet niet langer is toegestaan, blijkt de rechter namelijk wel te willen volstaan met de oplegging van een taakstraf,

6 De rechter kan ook volstaan met een schuldigverklaring zonder strafoplegging ex art. 9a Sr (rechterlijk pardon).

7 (Principale) hechtenis is de vrijheidsbenemende straf in het geval van overtredingen; in het geval van misdrijven betreft het gevangenisstraf.

8 Sinds 2001 is de taakstraf een zelfstandige straf in Nederland; de taakstraf kan voor maximaal 240 uur worden opgelegd. Art. 9 lid 2 luidt: 'Ten aanzien van misdrijven die worden bedreigd met een vrijheidsstraf of een geldboete of ten aanzien van overtredingen die worden bedreigd met een vrijheidsstraf kan, behoudens in bij de wet bepaalde gevallen, in plaats daarvan een taakstraf worden opgelegd.' 'Behoudens in bij de wet bepaalde gevallen' verwijst naar het taakstrafverbod ex art. $22 \mathrm{~b} \mathrm{Sr}$.

9 Voor de gevangenisstraf geldt het volgende. In geval van een gevangenisstraf van ten hoogte twee jaar kan deze straf geheel of gedeeltelijk voorwaardelijk worden opgelegd; in geval van een gevangenisstraf van meer dan twee jaar en ten hoogste vier jaar kan maximaal twee jaar voorwaardelijk worden opgelegd; in geval van een gevangenisstraf hoger dan vier jaar kan geen gedeelte van de straf voorwaardelijk worden opgelegd. 
bijvoorbeeld gezien de geringere ernst van het concrete feit, de persoon van de verdachte en/of de omstandigheden van het geval. En/of, omdat hij wil vermijden dat de verdachte zijn woning en/of baan en/of sociale netwerk kwijtraakt. En/of, omdat hij wil voorkomen dat de verdachte op negatieve wijze wordt beïnvloed door de detentie zelf en/of door gedetineerden. De rechter blijkt in praktijk het taakstrafverbod dan ook regelmatig te 'omzeilen', ofwel door te doen alsof artikel 22b Sr niet bestaat, ofwel door een (zeer) korte onvoorwaardelijke gevangenisstraf op te leggen (vaak gelijk aan het voorarrest, indien daarvan sprake is geweest), ofwel - en dat is helemaal het tegenovergestelde van wat de wetgever heeft beoogd - door een geldboete (lees: een lichtere straf dan de taakstraf) op te leggen (een geldboeteverbod bestaat immers niet). In de zogeheten Valkenburgse zedenzaak heeft de Hoge Raad zijn fiat verleend aan de 'omzeiling' van artikel 22b Sr middels de oplegging van een (zeer) korte onvoorwaardelijke gevangenisstraf, aangezien de wetgever nergens in de wetsgeschiedenis met zoveel woorden heeft aangegeven dat het om een substantiële vrijheidsbeneming moet gaan (HR 20 februari 2018, ECLI:NL:HR:2018:202). Hoewel het ook een principiële kwestie betreft (de rechter wil het liefst volledige straftoemetingsvrijheid en derhalve geen minimumstraffen anders dan de algemene strafminima), lijkt deze 'omzeiling' tevens voort te komen uit het bewustzijn van de rechter dat de gevangenisstraf diep in het leven van de mens ingrijpt nu het diens op één na hoogste goed, namelijk diens vrijheid, afneemt én dat van de gevangenisstraf in de regel weinig tot geen positieve effecten mogen worden verwacht op degene die hiertoe wordt veroordeeld. In die zin is en behoort de gevangenisstraf ultimum remedium te zijn.

De rechter mag geacht worden op de hoogte te zijn van de ineffectiviteit van de gevangenisstraf in termen van recidivereductie. Reeds in 2009 schreven de onderzoekers Dirkzwager, Lamet, Nieuwbeerta, Blokland en Van der Laan in een artikel in het door de Raad voor de rechtspraak uitgegeven magazine Rechtstreeks dat 'de resultaten van het bestaande onderzoek naar de effecten van detentie op toekomstig crimineel gedrag tot de voorzichtige conclusie [leiden] dat detentie geen dan wel een criminogeen effect heeft op herhaald crimineel gedrag' (Dirkzwager e.a., 2009: 24). In hetzelfde artikel stellen zij: 'Wanneer rechters gevangenisstraf opleggen moeten zij zich dus weinig illusies maken over het realiseren van speciale preventie. Met gevangenisstraf voorkomen zij waarschijnlijk geen recidive, en resocialisatie wordt waarschijnlijk ook niet gerealiseerd.' (Dirkzwager e.a., 2009: 28) De onderzoekers wijzen op het bestaan van andere strafdoelen, waaronder vergelding en maatschappijbeveiliging middels opsluiting, die de oplegging van gevangenisstraf in bepaalde gevallen toch kunnen legitimeren. Niettemin dient de vraag te worden gesteld of er alternatieven denkbaar zijn voor de (korte) gevangenisstraf die effectiever zijn in termen van recidivereductie.

Die alternatieven zijn er. Zo volgt uit onderzoek van Wermink, Blokland, Nieuwbeerta en Tollenaar uit 2009, waarin is gewerkt met een gematchte vergelijking, dat daders significant minder recidiveren na een taakstraf dan na een (korte) gevangenisstraf: 'Na werkstraffen recidiveerden daders minder, zowel op de korte als op de lange termijn - gemiddeld 50 procent minder veroordelingen over een 
periode van acht jaar. Dit wordt gevonden voor zowel mannen als vrouwen en op verschillende leeftijden.' (Wermink e.a., 2009: 224) Dat (korte) gevangenissenstraffen contraproductief zijn in termen van recidivereductie blijkt ook uit onderzoek van Blokland, Wermink, Robert en Maes uit 2015, waarin zij de recidive na elektronische thuisdetentie gematcht vergelijken met die na reguliere detentie: 'Na een jaar is 18 procent $(\mathrm{N}=182)$ van de regulier gedetineerde groep opnieuw gedetineerd geraakt tegenover vijf procent $(\mathrm{N}=45)$ van de elektronisch-toezichtgroep. Het verschil tussen beide groepen blijft ook op langere termijn bestaan, na drie en vijf jaar is respectievelijk 38 procent $(\mathrm{N}=373)$ en 46 procent $(\mathrm{N}=459)$ van de regulier gedetineerde groep opnieuw gedetineerd, terwijl dit voor de elektronisch-toezichtgroep respectievelijk 17 procent $(\mathrm{N}=167)$ en 24 procent $(\mathrm{N}=239)$ bedraagt.' (Blokland e.a., 2015: 51). Beide onderzoeken, die laten zien dat taakstraffen respectievelijk elektronische thuisdetentie effectiever zijn dan (korte) gevangenisstraffen in termen van recidivereductie, worden ondersteund door de meta-analyse van Nederlands recidiveonderzoek naar de effecten van strafrechtelijke interventies door Wartna, Alberda en Verweij uit 2013. Deze onderzoekers concluderen op basis van genoemde meta-analyse 'dat projecten gestoeld op het principe van "resocialisatie" in de loop der jaren betere resultaten te zien hebben gegeven dan sancties gericht op "afschrikking"' (Wartna e.a., 2013: 19). Taakstraffen en elektronische detentie focussen meer op resocialisatie dan (korte) gevangenisstraffen die vooral zijn ingegeven door vergelding, afschrikking en maatschappijbeveiliging middels opsluiting.

Alle bovenstaande onderzoeken plaatsen expliciet dan wel impliciet vraagtekens bij de afschrikkingstheorie die er - kort gezegd - van uitgaat dat de meest strenge sanctie (waarbij geldt dat de gevangenisstraf zwaarder moet worden geacht dan de taakstraf of elektronische thuisdetentie) de meest afschrikwekkende sanctie is en dientengevolge het meest effectief in termen van recidivereductie. De Britse criminoloog Cornwell maakt in zijn boek Criminal Deterrence Theory: The History, Myths \& Realities uit 2018 korte metten met deze theorie en concludeert op basis van de praktijk als volgt: 'From [...] evidence-based research as is available, it becomes clear that increasing sanctions severity and the use of short term imprisonment for deterrent purposes significantly fails to reduce recidivism, and probably encourages it' (Cornwell, 2018: 153). Niettemin lijkt de politiek nog steeds veel geloof te hechten aan de afschrikwekkende werking van de (gevangenis)straf, iets wat ook Cornwell (p. 153) signaleert: 'Though [...] perceptions of deterrence and its place within criminal justice have changed since the sixteenth century, its taken-for-granted status as a principal component of criminal punishment has rarely been robustly challenged.'

\section{Verkeersdelicten en taakstraffen}

Samen met het willen voorzien in vergeldingsbehoeften lijkt het geloof in de afschrikwekkende werking van de (gevangenis)straf eveneens ten grondslag te liggen aan het momenteel in het Nederlandse parlement aanhangige wetsvoorstel 
tot wijziging van de Wegenverkeerswet 1994 en het Wetboek van Strafrecht in verband met strafbaarstelling van zeer gevaarlijk rijgedrag en verhoging van de strafmaxima van enkele ernstige verkeersdelicten met het oog op versterking van de verkeershandhaving (kort: Wet aanscherping strafrechtelijke aansprakelijkheid ernstige verkeersdelicten) (Kamerstukken II [vergaderjaren], 35086). Dit wetsvoorstel vloeit voort uit onderzoek van het International Victimology Institute Tilburg (INTERVICT) (Van der Aa e.a., 2016) en dat van de Rijksuniversiteit Groningen (RUG) (Wolswijk e.a., 2017). In het INTERVICT-onderzoek stond onder meer de vraag centraal hoe slachtoffers van ernstige verkeersongevallen de strafprocedure en de uitkomst daarvan ervaren. Uit het onderzoek volgt dat slachtoffers tevreden zijn over de procedure voor zover het gaat om informatieverstrekking en bejegening door het Openbaar Ministerie en de rechter. Minder tevreden zijn zij echter met de uitkomst: meer dan 50\% van de slachtoffers vindt dat de dader voor een (veel) te licht strafbaar feit is gestraft, terwijl $65 \%$ van de slachtoffers de opgelegde straf (veel) te licht vindt. Beide bevindingen lijken overigens met elkaar samen te hangen. Immers, voorwaardelijk opzet (de laagste gradatie van opzet oftewel dolus) en roekeloosheid (de zwaarste vorm van schuld oftewel culpa) worden in verkeerszaken zelden bewezenverklaard, zo blijkt uit het RUG-onderzoek, waardoor de straf in de regel lager uitvalt dan door slachtoffers gehoopt en/ of verwacht. 'Het beeld uit de media - slachtoffers zijn ontevreden met de opgelegde straf - wordt in de huidige studie bevestigd', aldus de INTERVICT-onderzoekers (p. 11) (Claessen, 2017).

\section{Kader 1}

\section{Relevante wetsbepalingen uit de Wegenverkeerswet 1994}

\section{Artikel 5}

Het is een ieder verboden zich zodanig te gedragen dat gevaar op de weg wordt veroorzaakt of kan worden veroorzaakt of dat het verkeer op de weg wordt gehinderd of kan worden gehinderd.

\section{Artikel 6}

Het is een ieder die aan het verkeer deelneemt verboden zich zodanig te gedragen dat een aan zijn schuld te wijten verkeersongeval plaatsvindt waardoor een ander wordt gedood of waardoor een ander zwaar lichamelijk letsel wordt toegebracht of zodanig lichamelijk letsel dat daaruit tijdelijke ziekte of verhindering in de uitoefening van de normale bezigheden ontstaat.

\section{Artikel 8}

1 Het is een ieder verboden een voertuig te besturen, als bestuurder te doen besturen of als begeleider op te treden, terwijl hij verkeert onder zodanige invloed van een stof, waarvan hij weet of redelijkerwijs moet weten, dat het gebruik daarvan - al dan niet in combinatie met het gebruik van een andere stof - de rijvaardigheid kan verminderen, dat 
hij niet tot behoorlijk besturen of tot behoorlijk te begeleiden in staat moet worden geacht.

2 Het is een ieder verboden een voertuig te besturen, als bestuurder te doen besturen of als begeleider op te treden na zodanig gebruik van alcoholhoudende drank, dat:

a het alcoholgehalte in zijn adem bij een onderzoek hoger blijkt te zijn dan 220 microgram alcohol per liter uitgeademde lucht, dan wel

b het alcoholgehalte in zijn bloed bij een onderzoek hoger blijkt te zijn dan 0,5 milligram alcohol per milliliter bloed.

$[\ldots]$

\section{Artikel 175}

1 Overtreding van artikel 6 wordt gestraft met:

a gevangenisstraf van ten hoogste drie jaren of geldboete van de vierde categorie, indien het een ongeval betreft waardoor een ander wordt gedood;

b gevangenisstraf van ten hoogste een jaar en zes maanden of geldboete van de vierde categorie, indien het een ongeval betreft waardoor een ander lichamelijk letsel wordt toegebracht.

2 Indien de schuld bestaat in roekeloosheid, wordt overtreding van artikel 6 gestraft met:

a gevangenisstraf van ten hoogste zes jaren of geldboete van de vijfde categorie, indien het een ongeval betreft waardoor een ander wordt gedood;

b gevangenisstraf van ten hoogste drie jaren of geldboete van de vierde categorie, indien het een ongeval betreft waardoor een ander lichamelijk letsel wordt toegebracht.

3 Indien de schuldige verkeerde in de toestand, bedoeld in artikel 8, eerste, tweede [...] lid, [...] of indien het feit is veroorzaakt of mede is veroorzaakt doordat hij een krachtens deze wet vastgestelde maximumsnelheid in ernstige mate heeft overschreden, dan wel zeer dicht achter een ander voertuig is gaan rijden, geen voorrang heeft verleend of gevaarlijk heeft ingehaald kunnen de in het eerste en tweede lid bepaalde gevangenisstraffen met de helft worden verhoogd.

\section{Artikel 176}

[...]

4. Overtreding van de artikelen [...] 8 [...] wordt gestraft met gevangenisstraf van ten hoogste drie maanden of geldboete van de derde categorie.

\section{Artikel 177}

Overtreding van:

a de artikelen 5 [...] wordt gestraft met hechtenis van ten hoogste twee maanden of geldboete van de tweede categorie.

$[\ldots]$ 


\section{Artikel 178}

1 De in de artikelen 175 en 176 strafbaar gestelde feiten zijn misdrijven.

2 De in artikel 177 strafbaar gestelde feiten zijn overtredingen.

Het wetsvoorstel voorziet allereerst in een zelfstandige strafbaarstelling van zeer gevaarlijk rijgedrag waarvan levensgevaar of gevaar voor zwaar lichamelijk letsel te duchten valt (art. 5a WVW). Het betreft een concreet gevaarzettingsmisdrijf dat de bestaande lacune moet dichten tussen aan de ene kant artikel 5 WVW (het verwijtbaar veroorzaken van hinderlijk verkeersgedrag als overtreding) en aan de andere kant artikel 6 WVW (het veroorzaken van (zwaar) lichamelijk letsel of dood door schuld oftewel culpa in het verkeer als misdrijf); in feite gaat artikel 5a WVW over het veroorzaken van bijna-verkeersongevallen: 'Het is een ieder verboden opzettelijk zich zodanig in het verkeer te gedragen dat de verkeersregels in ernstige mate worden geschonden, indien daarvan levensgevaar of gevaar voor zwaar lichamelijk letsel voor een ander te duchten is.' Voorts legt de wetgever in artikel 175 lid 2 jo. 5a lid 1 WVW vast wat in ieder geval onder 'roekeloos rijgedrag' dient te worden verstaan. Daarmee is het voortaan niet langer exclusief voorbehouden aan de rechter om te bepalen wat onder 'roekeloosheid' dient te worden verstaan. Tot slot verhoogt de wetgever de strafmaat in artikel 5 WVW: de maximumstraf gaat van hechtenis van ten hoogste twee maanden of geldboete van de tweede categorie naar hechtenis van ten hoogte zes maanden of geldboete van de derde categorie. De strekking van het wetsvoorstel is duidelijk: het roept de rechter op tot strenger straffen bij verkeersdelicten.

Kader 2

Nieuwe en gewijzigde wetsbepalingen uit de Wegenverkeerswet 1994 na inwerkingtreding wetsvoorstel

Artikel $5 a$

1 Het is een ieder verboden opzettelijk zich zodanig in het verkeer te gedragen dat de verkeersregels in ernstige mate worden geschonden, indien daarvan levensgevaar of gevaar voor zwaar lichamelijk letsel voor een ander te duchten is. Als zodanige verkeersgedragingen kunnen de volgende gedragingen worden aangemerkt:
a onvoldoende rechts houden op onoverzichtelijke plaatsen;
b gevaarlijk inhalen;
c negeren van een rood kruis;
d over een vluchtstrook rijden waar dit niet is toegestaan;
e inhalen voor of op een voetgangersoversteekplaats;
f niet verlenen van voorrang;
g overschrijden van de krachtens deze wet vastgestelde maximum- snelheid;
h zeer dicht achter een ander voertuig rijden; 
i door rood licht rijden;

j tegen de verkeersrichting inrijden;

$\mathrm{k}$ het rijden een mobiel elektronisch apparaat vasthouden;

1 niet opvolgen van verkeersaanwijzingen van daartoe op grond van deze wet bevoegde personen;

m overtreden van andere verkeersregels van soortgelijk belang als die onder a tot en met l genoemd.

2 Bij de toepassing van het eerste lid wordt mede in aanmerking genomen de mate waarin de verdachte verkeerde in de toestand, bedoeld in artikel 8, eerste, tweede [...] lid.

Artikel 175

[...]

1 Indien de schuld bestaat in roekeloosheid, wordt overtreding van artikel 6 gestraft met:

a gevangenisstraf van ten hoogste zes jaren of geldboete van de vijfde categorie, indien het een ongeval betreft waardoor een ander wordt gedood;

b gevangenisstraf van ten hoogste drie jaren of geldboete van de vierde categorie, indien het een ongeval betreft waardoor een ander lichamelijk letsel wordt toegebracht. Van roekeloosheid is in elk geval sprake als het gedrag tevens als een overtreding van artikel 5a, eerste lid, kan worden aangemerkt.

2 Indien de schuldige verkeerde in de toestand, bedoeld in artikel 8, eerste, tweede [...] lid, [...] kunnen de in het eerste en tweede lid bepaalde gevangenisstraffen met de helft worden verhoogd.

\section{Artikel 176}

1 Overtreding van artikel 5 a wordt gestraft met gevangenisstraf van ten hoogste twee jaren of geldboete van de vierde categorie.

[...]

\section{Artikel 177}

1 Overtreding van de artikelen 5 [...] wordt gestraft met hechtenis van ten hoogste zes maanden of geldboete van de derde categorie. $[\ldots]$

Strikt genomen verplicht het wetsvoorstel de rechter niet in meer gevallen tot de oplegging van een onvoorwaardelijke gevangenisstraf op basis van het taakstrafverbod ex artikel 22b Sr dan nu het geval is. Deze verplichting geldt namelijk ook na inwerkingtreding van het wetsvoorstel uitsluitend in het geval van een dodelijk verkeersongeval waarbij sprake is van roekeloosheid; hierop staat namelijk een maximale gevangenisstraf van zes jaar, terwijl tevens sprake is van een ernstige inbreuk op de lichamelijke integriteit van het slachtoffer. Voor alle andere verkeersdelicten blijft artikel 22b Sr buiten toepassing, waardoor het de rechter vrij- 
staat in bepaalde gevallen te volstaan met een taakstraf - eventueel gecombineerd met een voorwaardelijke gevangenisstraf als 'afschrikwekkende stok achter de deur'. Echter, indien het wetsvoorstel in werking treedt, zullen veel meer dodelijke verkeersongevallen onder het taakstrafverbod komen te vallen dan thans het geval is, omdat de wetgever de term 'roekeloosheid' in het wetsvoorstel aanzienlijk oprekt in vergelijking met de huidige interpretatie ervan door de rechter. Uit de jurisprudentie blijkt immers dat de rechter roekeloosheid momenteel slechts in zeer uitzonderlijke gevallen bewezen verklaart, namelijk vrijwel uitsluitend in het geval van straatraces en kat-en-muis-spelen, situaties die zeer dicht tegen voorwaardelijk opzet aanzitten (Kooijmans, 2015).

Thans hanteert de rechter in het kader van het veroorzaken van (zwaar) lichamelijk letsel of dood door schuld in het verkeer ex artikel 6 WVW de oriëntatiepunten zoals weergegeven in tabel $1 ;^{10}$ voor artikel 5 (en art. 5a) WVW bestaan dergelijke oriëntatiepunten (nog) niet.

De oriëntatiepunten en de jurisprudentie laten zien dat de rechter bij veel verkeersongevallen ex artikel 6 WVW volstaat met de oplegging van een taakstraf - mogelijk gecombineerd met een voorwaardelijke gevangenisstraf en een rijontzegging voor een bepaalde duur. Eerst wanneer sprake is van alcoholgebruik én ernstige dan wel een zeer hoge mate van schuld, komt een onvoorwaardelijke gevangenisstraf in beeld. In een aantal gevallen gaat het om relatief korte gevangenisstraffen van twee, drie of vier maanden. Langere gevangenisstraffen (van zes maanden tot vier jaar) zijn gereserveerd voor die gevallen waarin sprake is van een combinatie van zwaar lichamelijk of dodelijk letsel, flink alcoholgebruik en/of ernstige dan wel een zeer hoge mate van schuld. In die zin wijken de oriëntatiepunten nogal af van de wettelijke maxima, wat niet vreemd is omdat het - de term zegt het al - om wettelijke maxima gaat.

De idee achter deze wellicht nogal afgemeten en mild ogende tabel is dat verkeersongevallen ex artikel 6 WVW culpoze delicten zijn en niet zelden tragische gebeurtenissen waarbij verdachten in zekere zin ook zelf slachtoffers zijn. Denk hierbij aan de even niet goed (genoeg) oplettende automobilist of aan de automobilist die een (kleine) inschattingsfout maakt. ${ }^{11}$ Denk ook aan verdachten die te hard rijden of die met een paar borrels te veel op achter het stuur gaan zitten. Niet om dergelijke gedragingen goed te praten, geenszins, maar deze mensen doen dit niet met de intentie anderen te schaden. Gebeurt dit onverhoopt toch, dan zitten veel van deze verdachten achteraf met een groot schuld- en/of schaamtegevoel dat ook hun leven en dat van hun achterban (ouders, partners, kinderen, enz.) op zijn kop zet (zie niet alleen het tweede voorbeeld uit de inleiding bij deze bijdrage, maar ook verscheidene andere bijdragen in dit themanummer).

10 Dit zijn door de zittende magistratuur zelf opgestelde oriëntatiepunten ten behoeve van de straftoemeting; deze oriëntatiepunten binden de individuele strafrechter in een concrete zaak overigens niet, maar zij worden doorgaans wel als leidraad gehanteerd. Zie: www.rechtspraak.nl.

11 Een aantal van deze gevallen valt uiteindelijk onder art. 5 WVW (verwijtbaarheid is hier voldoende) en niet onder art. 6 WVW (waarbij het moet gaan om verwijtbare grove onvoorzichtigheid). Zie onder meer: Rb. Limburg 4 mei 2018, ECLI:NL:RBLIM:2018:4288. 
Tabel 1 Oriëntatiepunten voor de rechter voor het bepalen van de straf

\begin{tabular}{|c|c|c|c|c|}
\hline \multicolumn{5}{|c|}{ Art. 6 WVW 1994 - veroorzaken verkeersongeval* } \\
\hline $\begin{array}{l}\text { Gevolgen slacht- } \\
\text { offer }\end{array}$ & Alcoholgebruik & $\begin{array}{r}\text { Aanmerkelijke } \\
\text { schuld }\end{array}$ & Ernstige schuld & $\begin{array}{l}\text { Zeer hoge mate } \\
\text { van schuld }\end{array}$ \\
\hline \multirow[t]{3}{*}{$\begin{array}{l}\text { Lichamelijk letsel, } \\
\text { tijdelijke ziekte }\end{array}$} & Geen alcohol & $\begin{array}{r}€ 1.000 \\
3 \text { mnd OBM }\end{array}$ & $\begin{array}{r}120 \text { uur TS } \\
6 \text { mnd OBM }\end{array}$ & $\begin{array}{c}2 \text { mnd GS ov } \\
\text { I jr OBM }\end{array}$ \\
\hline & Alcohol $<570 \mu \mathrm{g} /$ & $\begin{array}{r}120 \text { uur TS } \\
9 \text { mnd OBM }\end{array}$ & $\begin{array}{r}160 \text { uur TS } \\
18 \text { mnd } \\
\text { OBM }\end{array}$ & $\begin{array}{r}6 \text { mnd GS ov } \\
2 \text { jr OBM }\end{array}$ \\
\hline & Alcohol > $570 \mu \mathrm{g} /$ & $\begin{array}{r}140 \text { uur TS } \\
18 \text { mnd } \\
\text { OBM }\end{array}$ & $\begin{array}{r}3 \text { mnd GS ov } \\
2 \text { jr OBM }\end{array}$ & $\begin{array}{r}7 \text { mnd GS ov } \\
3 \text { jr OBM }\end{array}$ \\
\hline \multirow[t]{3}{*}{$\begin{array}{l}\text { Zwaar lichamelijk } \\
\text { letsel }\end{array}$} & Geen alcohol & $\begin{array}{r}120 \text { uur TS } \\
6 \text { mnd OBM }\end{array}$ & $\begin{array}{r}160 \text { uur TS } \\
\text { I jr OBM }\end{array}$ & $\begin{array}{r}4 \text { mnd GS ov } \\
2 \mathrm{jr} \text { OBM }\end{array}$ \\
\hline & Alcohol $<570 \mu \mathrm{g} /$ & $\begin{array}{r}160 \text { uur TS } \\
18 \text { mnd } \\
\text { OBM }\end{array}$ & $\begin{array}{r}6 \text { mnd GS ov } \\
2 \text { jr OBM }\end{array}$ & $\begin{array}{r}8 \mathrm{mnd} \text { GS ov } \\
3 \mathrm{jr} \text { OBM }\end{array}$ \\
\hline & Alcohol > $570 \mu \mathrm{g} /$ & $\begin{array}{r}3 \text { mnd GS ov } \\
2 \text { jr OBM }\end{array}$ & $\begin{array}{r}7 \text { mnd GS ov } \\
3 \mathrm{jr} \text { OBM }\end{array}$ & $\begin{array}{r}24 \text { mnd GS } \\
\text { ov } \\
4 \mathrm{jr} \text { OBM }\end{array}$ \\
\hline \multirow[t]{3}{*}{ Dood } & Geen alcohol & $\begin{array}{r}240 \text { uur TS } \\
\text { I jr OBM }\end{array}$ & $\begin{array}{r}6 \text { mnd GS ov } \\
2 \text { jr OBM }\end{array}$ & $\begin{array}{r}8 \text { mnd GS ov } \\
3 \mathrm{jr} \text { OBM }\end{array}$ \\
\hline & Alcohol $<570 \mu \mathrm{g} /$ & $\begin{array}{r}6 \text { mnd GS ov } \\
2 \text { jr OBM }\end{array}$ & $\begin{array}{r}12 \text { mnd GS } \\
\text { ov } \\
3 \mathrm{jr} \text { OBM }\end{array}$ & $\begin{array}{c}3 \mathrm{jr} \text { GS ov } \\
4 \mathrm{jr} \text { OBM }\end{array}$ \\
\hline & Alcohol > $570 \mu \mathrm{g} /$ & $\begin{array}{r}7 \text { mnd GS ov } \\
3 \text { jr OBM }\end{array}$ & $\begin{array}{r}24 \text { mnd GS } \\
\text { ov } \\
4 \mathrm{jr} \text { OBM }\end{array}$ & $\begin{array}{r}4 \mathrm{jr} \text { GS ov } \\
5 \mathrm{jr} \text { OBM }\end{array}$ \\
\hline
\end{tabular}

${ }^{*}$ TS = taakstraf; GS = gevangenisstraf; OBM = ontzegging rijbevoegdheid; mnd = maanden; jr $=$ jaren; ov = onvoorwaardelijk.

Let op: vindt er een verkeersongeval plaats met (zwaar) lichamelijk letsel of de dood van een derde tot gevolg en is er sprake van een schending van de verkeersregels (wat nogal snel het geval is), dan levert dit op basis van het aanhangige wetsvoorstel vrijwel automatisch roekeloosheid en dientengevolge strafverzwaring op (art. 175 lid 2 jo. 5a WVW); in het geval van een dodelijk verkeersongeval komt dan, zoals gezegd, het taakstrafverbod ex artikel 22b Sr om de hoek kijken, wat de facto betekent dat niet mag worden volstaan met de oplegging van een taakstraf. Het wetsvoorstel strekt tevens tot een strengere aanpak van schending van de verkeersregels, waardoor geen ongeval (maar een bijna-ongeval) wordt veroorzaakt, getuige het voorgestelde artikel 5a WVW.

Met zwaardere straffen, anders gezegd: door meer vergelding tracht dit wetsvoorstel de door INTERVICT en de RUG gesignaleerde kloof tussen de door de rechter opgelegde straf en de door de slachtoffers gewenste straf te dichten in het geval van ernstige verkeersdelicten. De vraag is evenwel of de dreiging met of de oplegging van een zwaardere straf (bijvoorbeeld een onvoorwaardelijke gevangenisstraf in plaats van een taakstraf) ook tot meer veiligheid zal leiden. Gezien de 


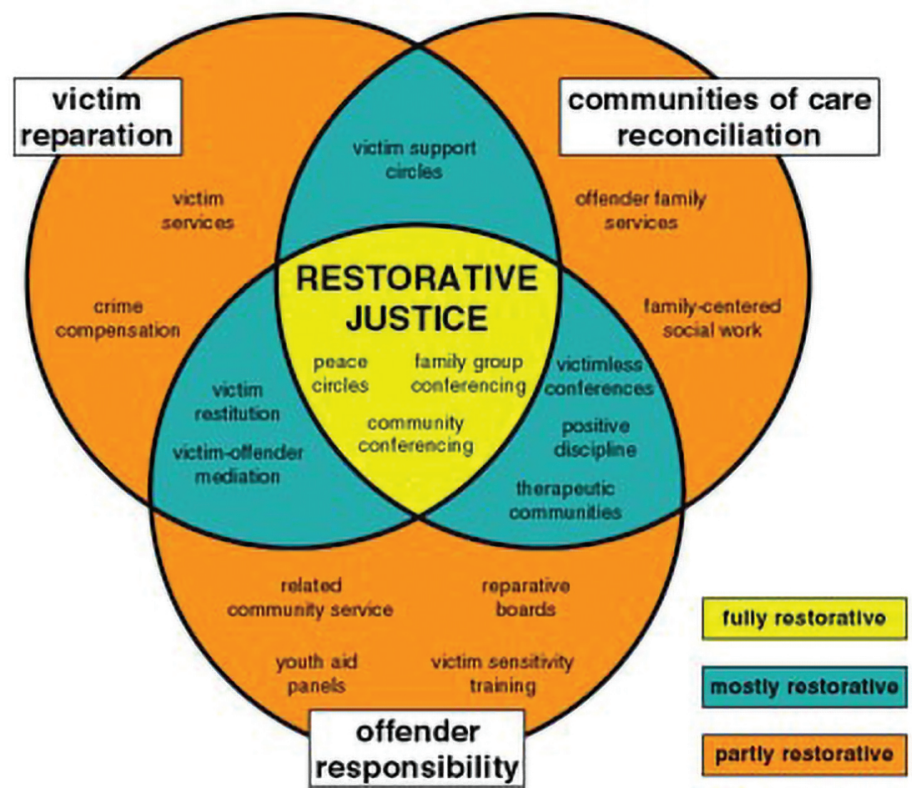

Figuur 1 Restorative practices typology (McCold \& Wachtel, 2003)

hiervoor in paragraaf 2 besproken onderzoeken valt dit nog te bezien, in ieder geval voor wat betreft de voorkoming van recidive middels speciale preventie c.q. afschrikking.

\section{Herstelrecht, verkeersdelicten en taakstraffen}

De herstelrechtdenkers McCold en Wachtel stellen dat herstelrechtvoorzieningen oftewel -modaliteiten volledig, grotendeels dan wel gedeeltelijk herstelgericht kunnen zijn; zelf spreken zij van een restorative practices typology (McCold \& Wachtel, 2003, waarin ook figuur 1 is opgenomen). Volledig herstelgericht zijn de herstelconferenties en -cirkels, omdat daarin alle primaire betrokkenen zijn opgenomen, namelijk dader, slachtoffer en gemeenschap. Grotendeels herstelgericht zijn bemiddeling en mediation, ${ }^{12}$ aangezien er daarin twee primaire betrokkenen zijn: dader en slachtoffer. Gedeeltelijk herstelgericht zijn die voorzieningen oftewel modaliteiten waarin (primair) slechts één betrokkene aanwezig is. Voor het slachtoffer kan men denken aan Slachtofferhulp Nederland en het Schadefonds Geweldsmisdrijven evenals de schadevergoedingsmaatregel ex artikel 36f Sr. Wat betreft de dader kan men denken aan wat McCold en Wachtel related community service noemen, vrij vertaald: taakstraffen, specifieker: taakstraffen die in verband staan met het delict en (desgewenst) met het slachtoffer en de gemeenschap. 
Taakstraffen bestaan in Nederland uit het verrichten van onbetaalde arbeid ten algemenen nutte voor de duur van maximaal 240 uur (art. 22c Sr). De gedachte hierachter is dat de dader actief verantwoordelijkheid neemt voor wat hij heeft misdaan en (op symbolische wijze) bijdraagt aan herstel oftewel wedergoedmaking.

Taakstraffen worden daadwerkelijk herstelgericht, wanneer in het kader van de te verrichten werkzaamheden een link wordt gelegd met het gepleegde delict en/of het slachtoffer en de gemeenschap. Er zijn inmiddels voldoende praktijkvoorbeelden te vinden waarin daders en slachtoffers tijdens een mediation in strafzaken afspraken maken over het verrichten van werkzaamheden door de dader jegens het slachtoffer of de nabestaanden die verband houden met het delict. Ook de officier van justitie of de rechter kan op basis van het dossier of het verhandelde ter zitting suggesties doen voor de inhoud van de op te leggen taakstraf. Hierbij kan worden gedacht aan de verkeerszaak die in 2016 speelde bij de Rechtbank Zeeland-West-Brabant (ECLI:NL:RBZWB:2016:4629) (Claessen, 2017: 1137). In deze zaak was de verdachte met zeer hoge snelheid achterop een auto gereden die stilstond voor een openstaande brug, waarbij het inzittende jonge echtpaar zwaar werd getroffen: de drie kinderen op de achterbank bleven ongedeerd, maar de man liep een dwarslaesie op en de vrouw verloor haar ongeboren kind. De rechtbank achtte schuld oftewel culpa in de zin van artikel 6 jo. 175 WVW bewezen. Zij woog bij de strafoplegging in het voordeel van verdachte mee, dat hij er blijk van had gegeven de ernst van het veroorzaakte leed bij de slachtoffers in te zien. Bovendien had de verdachte na het ongeval getracht met de slachtoffers in contact te komen; uiteindelijk is hij via een door Slachtoffer in Beeld (Perspectief Herstelbemiddeling) begeleid bemiddelingstraject met de slachtoffers in contact gekomen. Dit contact werd door zowel de verdachte als de slachtoffers nog steeds in stand gehouden. Opmerkelijk in deze zaak was - en vooral daardoor belandde zij landelijk in het nieuws - dat, hoewel de gevolgen van het ongeval voor het echtpaar zwaar waren, zij de verdachte hadden vergeven en zij de rechter zelfs verzochten om aan hem geen straf op te leggen, omdat ook hij de gevolgen van het ongeval levenslang met zich moet dragen. Mocht hij toch - conform de LOVSoriëntatiepunten - een taakstraf opgelegd krijgen, dan zouden zij graag zien dat de verdachte deze bij hen thuis zou mogen uitvoeren. De rechtbank merkte in haar vonnis op dat de noodzaak van vergelding in deze zaak moest worden gerelativeerd. Zij legde de verdachte een taakstraf op voor de duur van 120 uur, waarbij de suggestie werd gedaan om de taakstraf thuis bij de slachtoffers te verrichten. Daarnaast werd aan verdachte een voorwaardelijke rijontzegging opgelegd voor de duur van een jaar met een proeftijd van twee jaar. Ook wanneer het slachtoffer niet wenst dat de dader werkzaamheden voor hem of haar verricht, kan een taakstraf herstelgericht vorm krijgen. Bij verkeersongevallen zou kunnen worden gedacht aan het onbetaald verrichten van werkzaamheden in een revalidatiekliniek waar ook slachtoffers van verkeersongevallen verblijven en bezig zijn met hun revalidatie (zie de bijdrage van Joke Niekamp in dit themanummer). Voorstelbaar is dat de confrontatie met het leed dat verkeersongevallen bij de slachtof- 
fers ervan teweegbrengt, een aanzienlijke impact heeft op de veroorzakers van dergelijke ongevallen.

\section{Ideaalbeeld inzake de sanctionering van verkeersongevallen: een continuüm}

$\mathrm{Nu}$ de thema's taakstraffen, verkeersdelicten en herstelrecht zijn besproken en met elkaar in verband zijn gebracht, volgt in deze paragraaf mijn ideaalbeeld inzake de sanctionering van (bijna-)verkeersongevallen. In plaats van overtreding van artikel 5 WVW, artikel 5a WVW en artikel 6 WVW per definitie streng te bestraffen (door in bepaalde gevallen zelfs de oplegging van een onvoorwaardelijke gevangenisstraf voor te schrijven), zou ik willen pleiten voor een aanpak die primair gericht is op herstel en speciale preventie c.q. recidivereductie.

Deze aanpak houdt allereerst in dat onderzocht wordt of de verdachte en het slachtoffer of de nabestaanden behoefte hebben aan mediation - wanneer het een verkeersdelict met slachtoffer of nabestaanden betreft. Is dat het geval, dan kunnen de dader en het slachtoffer of de nabestaanden afspraken maken over herstelwerkzaamheden die worden neergelegd in een schriftelijke overeenkomst waarmee de officier van justitie dan wel de rechter rekening houdt (art. 51h lid 2 $\mathrm{Sv}$ ). Worden geen afspraken gemaakt tussen de partijen of is er geen behoefte aan mediation, dan houdt deze aanpak in dat de officier van justitie dan wel de rechter alsnog zo herstelgericht mogelijk sanctioneert (het staat de officier van justitie en de rechter altijd vrij om bij de partijen te polsen hoe zij tegenover een herstelgerichte sanctionering staan); ook wanneer het gaat om overtredingen van artikel 5 of het voorgestelde artikel 5 a WVW waarbij geen direct slachtoffer betrokken hoeft te zijn, verdient een herstelgerichte sanctionering de voorkeur. In dat verband wordt in beginsel gepleit voor de oplegging van een herstelgerichte taakstraf, i.e. een taakstraf waarbij een link wordt gelegd met het delict en/of het slachtoffer en de gemeenschap. Ook in de gevallen waarin momenteel een korte gevangenisstraf wordt opgelegd (tot drie of vier maanden), dient de mogelijkheid van een herstelgerichte taakstraf serieus te worden overwogen.

In paragraaf 2 zijn reeds de gunstige effecten van de taakstraf wat betreft recidivereductie besproken in vergelijking met (korte) gevangenisstraffen. Of deze gunstige effecten nu te danken zijn aan de taakstraf zelf, aan het uitblijven van de negatieve consequenties van de gevangenisstraf of aan een combinatie van beide, feit is dat de recidive significant lager ligt na een taakstraf dan na een (korte) gevangenisstraf. Vermeldenswaardig is dat momenteel ca. $75 \%$ van alle gedetineerden een gevangenisstraf uitzit van drie maanden of minder; ca. $25 \%$ zit maximaal twee weken vast (zie: www.dji.nl). Bij al deze (zeer) korte gevangenisstraffen zou in mijn visie in beginsel het alternatief van de taakstraf serieus in overweging moeten worden genomen. Uitgangspunt zou moeten zijn: taakstraf, tenzij sprake is van contra-indicaties ontleend aan de persoon van de verdachte en/of de ernst van het feit; afwijking van de hoofdregel - inhoudende dat toch wordt gekozen voor de oplegging van een gevangenisstraf - zou door de officier 
van justitie in zijn requisitoir en door de rechter in zijn vonnis uitgebreid gemotiveerd moeten worden waarom hij daarvoor kiest en welk(e) doel(en) hij daarmee beoogt. In paragraaf 3 bleek dat een aantal veroorzakers van verkeersongevallen ex artikel 6 WVW ook tot deze grote groep kortgestraften behoren. Ook zij zouden in beginsel in aanmerking moeten komen voor een taakstraf - beter nog: een herstelgerichte taakstraf - in plaats van een korte gevangenisstraf. In mijn ideaalbeeld zou bovendien de leerstraf opnieuw worden ingevoerd als (met een werkstraf te combineren) variant van de taakstraf in het volwassenenstrafrecht; momenteel is de leerstraf enkel nog een vorm van de taakstraf in het jeugdstrafrecht.

In mijn ideaalbeeld zou ook elektronische thuisdetentie een zelfstandige hoofdstraf zijn en een mogelijk alternatief voor gevangenisstraffen tot en met zes maanden (Claessen, 2015). Daarmee zou ook bij ernstige verkeersongevallen ex artikel 6 WVW de mogelijkheid ontstaan om een taakstraf te combineren met elektronische thuisdetentie, waarmee tot op zekere hoogte tegemoet kan worden gekomen aan bestaande vergeldingsbehoeften, maar waarmee tegelijkertijd de negatieve effecten van reguliere detentie kunnen worden voorkomen. Voor de qua schuld en gevolgen zwaarste verkeersongevallen ex artikel 6 WVW zal een onvoorwaardelijke gevangenisstraf onvermijdelijk blijven; een zo veel mogelijk herstelgerichte detentie waarbij eveneens aandacht wordt besteed aan het gepleegde delict en/of het slachtoffer en de gemeenschap, heeft in die gevallen de voorkeur.

De volledig herstelgerichte modaliteiten, waaronder de herstelconferentie (zie: Claessen e.a., 2018), heb ik niet besproken in mijn ideaalbeeld. Ik wil hiermee geenszins de indruk wekken dat de herstelconferentie in het geval van verkeersdelicten geen meerwaarde zou kunnen hebben, integendeel. Zeker bij ernstige verkeersongevallen ex artikel $6 \mathrm{WVW}$ is het alleszins voorstelbaar dat zij een grote impact hebben op alle betrokkenen, die mijns inziens dan ook dienen te worden uitgenodigd en gestimuleerd om deel te nemen aan het hersteltraject. Ook voor vertegenwoordigers van belangengroepen die opkomen voor meer verkeersveiligheid kan daarin een rol zijn weggelegd, terwijl ook de gemeente die verantwoordelijkheid is voor de verkeerssituatie een belangrijke rol kan spelen. Echter, nu in Nederland vooralsnog de meeste aandacht uitgaat naar grotendeels en gedeeltelijk herstelgerichte voorzieningen oftewel modaliteiten, ligt mijn focus in deze bijdrage daarop. In de toekomst zie ik graag een verdere ontwikkeling van volledig herstelgerichte voorzieningen oftewel modaliteiten in Nederland, ook in het geval van ernstige verkeersongevallen ex artikel 6 WVW.

Tot slot wil ik er nog op wijzen dat bemiddeling en mediation ook een rol kunnen spelen in de politiefase en niet alleen in de OM-, ZM- en tenuitvoerleggingsfase. In de praktijk blijkt echter nog steeds dat de politie slachtoffers en daders in die fase vaak 'uit elkaar houdt', mede omdat zij denkt dat partijen dan nog niet klaar zijn voor contact met elkaar (zo ook in het tweede voorbeeld uit de inleiding bij deze bijdrage). In mijn ideaalbeeld stelt de politie beide partijen op de hoogte van het bestaan van bemiddeling en mediation, geeft zij desgewenst meer informatie 
over beide en onderzoekt zij zorgvuldig wat de behoeften van slachtoffers en daders zijn op dat punt.

\section{Uitleiding}

Ik ben mij ervan bewust dat mijn ideaalbeeld, zoals uiteengezet in de vorige paragraaf, indruist tegen de punitieve hoofdstroom, zoals deze onder meer tot uitdrukking komt in het wetsvoorstel 'Aanscherping strafrechtelijke aansprakelijkheid ernstige verkeersdelicten'. De vraag is echter of strenger straffen alleen de oplossing gaat kunnen zijn voor het gesignaleerde onbehagen bij de aanpak van verkeersdelicten. Het bieden van de mogelijkheid tot (kanalisatie van emoties in het kader van) bemiddeling en mediation aan slachtoffers/nabestaanden, het geven van gedegen voorlichting over de preventieve werking van sancties aan de burger en het opleggen van herstelgerichte taakstraffen en detentie aan daders lijken in dit verband minstens zo belangrijk. De vraag is en blijft: hoeveel vergelding vinden wij met zijn allen voldoende en hoeveel ruimte blijft er over om constructief, betekenisvol en toekomstgericht te kunnen sanctioneren? Vergelding, afschrikking en onschadelijkmaking enerzijds en resocialisatie, rehabilitatie en herstel anderzijds zullen op gespannen voet met elkaar blijven staan. Van belang is oog te houden voor beide. Deze bijdrage tracht tegenwicht te bieden aan de door de politiek voorgestelde eenzijdig punitieve aanpak van ernstige verkeersdelicten.

\section{Literatuur}

Aa, S. van der, M. Groenhuijsen, K. Lens \& M. Lanslots (2016) Over de strafrechtelijke reactie op (ernstige) verkeersdelicten. Tilburg: INTERVICT.

Bakker, F.S. (2016) Het taakstrafverbod van artikel 22b Sr: is de rechter ongehoorzaam?. Delikt \& Delinkwent, 23(5), 289-305.

Blokland, A., H. Wermink, L. Robert \& E. Maes (2015) Wederopsluiting na elektronische detentie en reguliere detentie in België. Tijdschrift voor Criminologie, 57(1), 31-58.

Claessen, J. (2015) Wat wij van onze zuiderburen kunnen leren: elektronische detentie in het strafrecht. Nieuwsbrief Strafrecht, 19(8), 588-590.

Claessen, J. (2017) Punitief eenrichtingsverkeer in art. 6 WVW-zaken? Geef ruim baan aan de weg die naar herstel leidt!. Nieuwsbrief Strafrecht, 21(14), 1333-1339.

Claessen, J., J. Blad, G.J. Slump, A. van Hoek, A. Wolthuis \& Th. de Roos (2018) Voorstel van Wet strekkende tot de invoering van herstelrechtvoorzieningen in het Wetboek van Strafvordering, inclusief Memorie van Toelichting. Oisterwijk: Wolf Legal Publishers.

Cornwell, D.J. (2018) Criminal Deterrence Theory: The History, Myths \& Realities. Portland: Eleven International Publishing.

Dirkzwager, A., W. Lamet, P. Nieuwbeerta, A. Blokland \& P. van der Laan (2009) Na detentie: de gevolgen van rechtspraak. Rechtstreeks, 1.

McCold, P. \& T. Wachtel (2003) In Pursuit of Paradigm: A Theory of Restorative Justice. Zie: www.iirp.edu/pdf/paradigm.pdf.

Kooijmans, T. (2015) Door roekeloosheid getriggerd. Ars Aequi, 2, 130- 135. 
Wermink, H., A. Blokland, P. Nieuwbeerta \& N. Tollenaar (2009) Recidive na werkstraffen en na gevangenisstraffen. Een gematchte vergelijking. Tijdschrift voor Criminologie, 51(3), 211-227.

Wartna, B., D. Alberda \& S. Verweij (2013) Een meta-analyse van Nederlands recidiveonderzoek naar de effecten van strafrechtelijke interventies. Tijdschrift voor Criminologie, 1, 3-23.

Wolswijk, H.D., A. Postma \& B.F. Keulen (2017) Ernstige verkeersdelicten. Groningen: RUG. 